\title{
Çin'in Ortadoğu Politikası: Süreklilik ve Değişim
}

\author{
Hatice Çelik*
}

\section{Öz}

Bu çalışmada 21. Yüzyılda, modern uluslararası sistemin kendini her alanında görünür kılan aktörü Çin Halk Cumhuriyeti'nin (buradan sonra Çin veya ÇHC olarak ifade edilecektir) Ortadoğu coğrafyasına yönelik politikaları analiz edilecektir. Çalışma üç bölümden oluşmaktadır. Birinci bölümde literatürde sıklıkla yükselen güç olarak tanımlanan Çin’in yükselişi tartışılacak; literatürdeki bahse konu yükselişe dair yapılan tanımlama ve anlamlandırma giriş̧imleri ele alınacaktır. İkinci bölümde Çin'in yükselişi olarak ifade edilen süreçle birlikte küresel düzeyde nasıl bir dış politika gündemi oluşturduğu ve izlediği incelenerek Ortadoğu coğrafyasına ayrı bir önem verip vermediği anlaşılmaya çalışılacaktır. Üçüncü bölümde ise Çin'in Ortadoğu politikasını şekillendirirken nasıl bir yol izlediği, hangi noktaları referans alarak politika ürettiği ve nasıl mekanizmalar aracılığıyla bu politikaları hayata geçirme çabasında olduğu anlaşılmaya çalışılacaktır. Sonuç kısmında, Çin'in Ortadoğu’ya yaklaşımında yakaladığı fırsatlar ve karşılaştığı/karşılaşabileceği riskler ortaya konmaya çalışılacaktır.

Anahtar Kelimeler: Çin, Ortadoğu, Dış Politika, Yükselen Güç, Enerji, İş̧birliği.

\section{Middle Eastern Policy of China: Continuity and Change}

\section{Abstract}

In this study, it is aimed to investigate the policies of People's Republic of China towards Middle Eastern geography, which made itself visible in almost all areas of modern international system. This paper consists of three parts. In the first part, China's rise that is being described as a "rising power" in the literature frequently will be discussed and the initiatives for definition and explanation for this "rise" will be touched upon. In the second part, it will be focused on how a foreign policy agenda China is creating and how it follows its agenda at the global level. In this regard, it will be tried to understand whether China is putting a special emphasis on Middle Eastern geography. In the third part, it will be figured out what kind of a pattern China is following regarding its Middle Eastern policy, based on which points China is producing its policies and through which mechanisms China is working to implement its prospective agenda. In the conclusion part, it will be aimed to present the opportunities that China has grasped considering its Middle Eastern policy and challenges that China has faced within this geography.

Keywords: China, Middle East, Foreign Policy, Rising Power, Energy, Cooperation.

*Dr. Öğr. Üyesi | Ankara Sosyal Bilimler Üniversitesi, Doğu ve Afrika Araştırmaları Enstitüsü | hatice.celik@asbu.edu.tr ORCID: 000-0003-1409-8865 | DOI: 10.36484/liberal.683338

Liberal Düşünce Dergisi, Yıl: 25, Sayı: 97, Kış 2020, ss. 31-46.

Gönderim Tarihi: 1 Şubat 2020 | Kabul Tarihi: 17 Mart 2020 


\section{Giriş: Çin'in Yükselişi}

Dünya tarihi pek çok farklı aktörün yükselişine ve çöküşüne sahne olmuştur. Bu yükseliş ve çöküşler on yıllarla ifade edilemeyecek kadar uzun, çoğu zaman yüzyıllık dilimlerle ifade edilebilecek süreleri kapsamıştır. Portekiz, İspanyol, Hollanda, Osmanlı, Fransız, İngiliz İmparatorluklarının ardından Amerika Birleşik Devletleri (ABD) bu rolü ele geçirmiş ve II. Dünya Savaşı'ndan sonra oluşturulan yeni düzenin hem kurucusu hem koruyucusu pozisyonunu ele geçirmiştir. Ancak Soğuk Savaş'in iki kutuplu düzeninin Sovyetler Birliği'nin dağılmasıyla sona ermesi, küresel ilişkileri yeni bir düzleme oturtmuştur. Bu yeni düzlemde ABD’nin karşısında kendi gücüne denk başka bir aktör yerine kendi gücüne denk olmayan fakat bu potansiyele sahip başka aktörler belirmiştir. Böylece çok kutuplu dünya olarak tanımlanan yeni düzen şekillenmeye başlamış ve sistem içindeki devam eden inişler çıkışlar doğrultusunda şekillenişini sürdürmektedir. Bahse konu çok kutuplu düzenin aktörlerinden biri var ki Soğuk Savaş benzeri iki kutuplu bir düzen oluşma ihtimalinde ABD’nin karşısında yer alabileceği ihtimali çok sayıda akademik çalışmada yer almaktadır. Bu ihtimali var eden ülke Çin'dir.

Çin, içinde bulunulan yüzyılın en dikkat çekici ülkelerinden biridir. Bu çekicilik sosyal bilimlerin her alanında kavramsal tartışmalarda kendine yer bulmakla beraber aktif dış politika tartışmalarında da kendini sıklıkla göstermektedir. Çin'in kalkınmasını ve farklı alanlarda daha görünür hale gelmesini, yükselen Çin olarak özetleyebilecek süreç farklı coğrafyalarda da etki oluşturmaktadır. Soğuk Savaş yıllarında Sovyetler Birliği ile aynı blokta yer alan, ancak belli dönemlerde aralarında ayrışmalar yaşayan Çin, günümüzde özellikle ekonomik alandaki başarısı sayesinde siyasi alanda da benzer bir yükseliş ve güçlenme potansiyeli taşıdığı izlenimini ve beklentisini yaratmaktadır.

1970'lı yılların sonunda Deng Xiaoping ile başlayan dişa açılma süreci Çin'i ekonomik olarak kalkındırmaya başlamış ve bu sayede yaklaşık 40 yıldır aralıksız büyüyen bir ekonomik performans sağlanmıştır. Bu performans Çin'i bugün ABD’nin ardından ikinci büyük ekonomik güç olma noktasına yerleştirmiştir. Bazı akademisyenler Çin'in yükselişini uluslararası sistem içinde yeni bir süper gücün doğuşu olarak nitelendirse de Çin devlet başkanları bunu her fırsatta reddetmekte ve amaçlarının "barışçıl yükseliş" (peaceful rise) olduğunu, ABD’nin bu yüzyılda üstlendiği rolü devralma ve hegemon bir güç olma gibi bir niyetlerinin olmadığını ifade etmektedirler. Fakat siyasal bir liderlik hedefi olmasa bile böylesi devasa bir ekonomiyi istikrarlı görünümde tutmaya devam etmek için çalışır halde kalmasına devam etmek mecburidir. $\mathrm{Bu}$ çalışmanın sürdürülebilir olması ise enerji ihtiyacının mümkün olduğunca 
aksamadan karşılanabilmesine bağlıdır. Bu noktada ise Çin'in enerji ihtiyacının önemli sağlayıcılarından olan ülkelerin bulunduğu Ortadoğu coğrafyası Çin için hayati önem arz etmektedir. Elbette Çin'in Ortadoğu bölgesine yönelik tutumunun salt enerji bağımlılığı ile açıklanması yeterli olamayacaktır. Hâlihazırda bölgenin birçok gücün varlığını sürdürdüğü bir alan olduğu hatırlandığında, Çin'in Ortadoğu'daki varlığının daha küresel bir etki alanı mücadelesi olarak tanımlanması daha kapsayıcı bir açıklama olabilir.

\section{Çin’in Küresel Dış Politikası ve Ortadoğu'nun Yeri}

Son yıllarda Çin'in dış politikası üzerine yapılan akademik çalışmalar geniş bir literatür oluşturmuş/oluşturmaya devam etmektedir. Çin'in kendi bölgesi olan Asya, yatırımlarıyla varlığını güçlendirdiği Afrika ve ABD’nin arka bahçesi olarak gördüğü Latin Amerika bölgesi ile ilişkileri ayrı ayrı ve derinlemesine ele alınırken Ortadoğu bu bölgeler arasında akademik anlamda görece ihmal edilmiştir. Söz konusu ihmal durumu akademik alanla sınırlı kalmayarak dış politika alanında da kendini hissettirmiş ve Çin'in Ortadoğu politikası diğer bölgelere kıyasla üzerine daha az ilgi çekebilmiştir. Bunun sebebinin ise, bilhassa Batılı güçlerin kendilerine Ortadoğu bölgesinde nüfuz alanları oluşturabilmiş olmalarına karşın, Çin'in hala bir dış güç ya da dışarda kalan güç (outsider) olarak algılanıyor olduğu iddia edilmektedir (Shichor, 1979: xi). Bu algının nereden kaynaklandığının anlaşılabilmesi için Çin dış politikasının barındırdığı sürekliliklerin ve yaşadığı değişimlerin anlaşılması elzemdir. Zira Çin'in Ortadoğu'ya yönelik politikaları tarihsel ve analitik olarak incelenirken literatürde farklı yöntemler benimsenmiştir. Bunlar arasında tarihsel süreci anlatırken özellikle II. Dünya Savaşı'ndan günümüze dek gelen çalışmaların bazılarında daha detaylı dönem ayrımına gidilmiş bazılarında ise iki dönemden oluşan yaklaşım sergilenmiştir. İlkine örnek olarak Guang Pan'ın 'China's Success in the Middle East' çalışması verilebilir. Pan, çalışmasında Çin’in Ortadoğu politikalarını 1949-1955, 1956-1966, 1966-1976 ve 1977'den makalenin yayımlandığı 1997 tarihine dek dönemlere ayırarak ele almıştır (Pan, 1997).

Literatürdeki bir diğer çalışmada ise II. Dünya Savaşı’ndan kitabın basım tarihi olan 2014 yılına kadar Çin-Ortadoğu ilişkileri ikili ilişkiler bazında incelenmesine rağmen bu süreçte iki ana dönem belirlenmiştir. Bunlar 1949-1978 ve 1978 sonrası dönemdir (Olimat, 2014). Bu çalışmada ise literatürdeki ikinci eserin izlediği yöntem benimsenmiş ancak ilaveten Çin Devlet Başkanı Xi Jinping'in iktidara geldiği yll olan 2013'ten günümüze dek olan dönem ayrı bir dönem olarak incelenecektir. Bu doğrultuda Çin'in Ortadoğu yaklaşımı 1949- 
1978, 1978-2013 ve 2013'ten günümüze dönemleri şeklinde ele alınacaktır. Bu üç dönemde Çin dış politikası gerek kendi iç meseleleri gerek çok sayıdaki uluslararası olaylar ve dönüşümler yüzünden kimi değişimler yaşamış; ancak Ortadoğu'ya yönelik algısında ve politikalarında süreklilikler de gözlemlenmiştir. Bu değişimlerin ve sürekliliklerin neler olduğuna her dönem içinde ayrı ayrı değinilecektir.

\section{9-1978 Döneminde Çin Dış Politikası ve Ortadoğu}

Çin'in kuruluşundan ekonomisini dışarıya açtığı yıla kadarki süreyi kapsayan bu süre zarfında dış politikaya yön veren liderlerin yaklaşımlarının genel hatlarıyla açıklanması gerekmektedir. Bunlardan ilki Çin devletinin ve Çin Komünist Partisi'nin kurucusu olan Mao Zedong'un uluslararası ilişkilere dair ortaya koyduğu bakıştır. Mao'nun “intermediate zone theory” olarak bilinen bu yaklaşımı dönemin Çin diş politikasını şekillendirmiştir. Mao Zedong, bu fikri yaklaşımı, 1946 yılında Amerikalı gazeteci Anna Louise Strong ile gerçekleştirdiği mülakatta ortaya atmıştır. II. Dünya Savaşı'nın ardından özellikle İngilizler ve Fransızlar Ortadoğu'daki hâkimiyetlerini kaybetmeye başlamış ve bu alan yeni bir mücadele alanına dönüşmüştür. Mao, bu alanı "intermediate zone" şeklinde tanımlamış ve bu alanın artık ABD ile Sovyetler Birliği arasında yaşanacak bir rekabetin coğrafi alanı olarak görmüştür. Başka bir ifade ile II. Dünya Savaşı sonrası belirlenecek olan uluslararası ilişkiler düzeninde bir nevi güç boşluğu yaşanan Ortadoğu'ya hâkim olma mücadelesinde yaşanacaklar belirleyici olacaktı (Takahashi, 1990:1). Mao'nun ortaya koyduğu bu perspektif esasen Çin'in bir ulus devlet olarak kurulduğu ilk yıllardan itibaren Ortadoğu'ya atfettiği önemi açıcça göstermektedir.

1949'tan 1978'ye kadar geçen sürede Çin ve Ortadoğu arasındaki ilişkiler hızlı bir gelişme seyri izlemiştir. Yukarıda bahsedilen "intermediate zone" esasen Mao'nun daha kapsamlı bir teorisi olan World Zone Teorisi'nin bir parçasıdır. Mao bu teorisinde dünyayı Çin'in güvenliği, ilerlemesi ve modernizasyonu için jeo-stratejik öneme sahip olma bağlamında 3 bölgeye ayırmıştır (Olimat, 2014: 4). Bu teorinin özünde yatan 1940'lı ve 1950'li ylllardaki "tek alan" (one intermediate zone) fikrine, 1960'l ylllarda "iki alan" (two intermediate zones) fikri eklenmiş ve teori 1970'li ylllarda resmi olarak formüle edilmiştir (An, 2013: 35). Mao, Ortadoğu bölgesini "intermediate zone" olarak görüyor ve Çin'in bağımsızlığını ve istikrarını koruyabilmesi için hayati öneme sahip olduğunu düşünüyordu. Çinlilere göre, bu alanın düşman bir gücün eline geçmesi sadece üçüncü dünya savaşını başlatmayacak, aynı zamanda Çin'in hayatta kalabilmesini de tehlikeye atacaktı (Shichor, 1979: 2). 
Ayrıca, 'orta alan' olarak görülen Ortadoğu bölgesinde herhangi bir gücün başat güç olarak nüfuz sağlaması da aynı oranda önemli bir risk olarak görülmekteydi. Bu bağlamda, Mao'nun liderliği döneminde Çin'in Ortadoğu'ya bakışının Çin'in güvenliği ile ilişkilendirilerek mümkün olduğunca istikrarlı bir yapıda kalmasının sağlanması şeklinde ifade edilebilir.

Ortadoğu'ya önem vermekle birlikte, Çin kuruluşunu izleyen yıllarda iç politik meselelere odaklanmış olmasından ötürü, bu bölgeye teoride verilen önemi pratiğe yansıtamamıştır. Elbette bu durum bölgenin Batı emperyalizminin etkisinden kurtulamamış ve bağımsızlık mücadelelerin devam ediyor oluşu ile doğrudan ilintiliydi (Daher, 2009: 18). 1950’li yılların ortalarına gelindiğinde çok az sayıda bölge ülkesi (ayrıca Arap Ligi 1950 yılının Ağustos ayında yaptığı oylama ile Çin halkını temsilen Tayvan'ı tanıma kararı almıştır) ile diplomatik ilişkiler kurulabilmişti. Zira 1949 yılında ÇHC kurulmadan önce Koumintang hükümeti (Tayvan) bölge ülkeleri ile zaten meşru devlet olarak ilişki kurmuştur. Öte yandan, ÇHC, diplomatik ilişkilerini tesis ederken tek Çin yaklaşımında ısrarcı olduğu için bölge ülkelerinin de bit tercih yapması gerekmekteydi. ÇHC, hükümetini Çin halkının temsilcisi olarak tanıyan ilk Ortadoğu devleti de 9 Haziran 1950'de İsrail olmuştur. Ancak burada dikkat edilmesi gereken nokta bazı ülkelerin Çin'i tanımanın ardından diplomatik ilişkileri resmi olarak hemen başlatmamış olduğudur. Ancak tanıma kararı kazanımı bile ilk etapta Çin tarafınca başarı olarak kabul edilmekteydi. Diplomatik misyonların haricinde Çin'in Ortadoğu ülkeleri ile ilk doğrudan teması 1955 yılının Nisan ayında Endonezya’da gerçekleştirilen 29 Asya ve Afrika ülkesinin katıldığı Bandung Konferansı'nda olmuştur. ${ }^{1}$ Zira o tarihlerde Birleşmiş Milletler'in bir üyesi olmayan Çin (bugün Tayvan olarak bilinen ve resmi adı Çin Cumhuriyeti olan ada Çin, Birleşmiş Milletler (BM) tarafından tanınmaktaydı, ancak ana kara Çin tanınmıyordu), Bandung Konferansı'nda kendine uluslararası bir platformda konuşabilme fırsatı bulmuştu.

Bandung Konferansı'ndan sonra Çin'in en büyük kazanımı bölge ülkelerindeki diplomatik temsilciliklerinin sayısını artırmak olmuştur. 25 Ağustos 1958'de Irak ile diplomatik ilişkiler kurulmuştur. 1956 yılında Mısır Çin ile diplomatik ilişkilerini başlatmış; bu hareketi Suriye ve Yemen takip etmiştir. Bandung Konferansı'na Çin'i delegasyonun lideri olarak katılan Başbakan Zhou Enlai (Choi En-Lai) konferansa katılan ülke liderleriyle yakın temaslar kurmaya çalışmıştır. Buradaki en temel hedefin de Çin'in Tayvan'dan ziyade

1 Çin'in Ortadoğu ile elbette 1949 yılından önce de ilişkisi bulunmaktadır; fakat bu çalışmada günümüzdeki ulus devlet formundaki haliyle ele alınan Çin söz konusu olduğu için ilişkilerin başlangıç noktası olarak 1949 kabul edilmiştir. 1949'tan önceki ilişkilerin kısa bir değerlendirmesi için bkz. Yitzhak Shichor'un The Middle East in China's Foreign Policy: 1949-1977, s. 9-12. 
kendisinin diplomatik tanınırlığını artırma olduğu açıkça görülmektedir. Bu temel hedefin yanı sıra, Zhou'nun de Bandung Konferansı'ndaki konuşmasında uzun yer ayırdığı bir başka konu daha bulunmaktadır. Bu, sömürge karşıtlığ1 ve bununla mücadele konusudur. Kendisi bunu sadece siyasi mücadele olarak değil ekonomik bir mücadele olarak da gördüğünü şu sözlerle ifade etmiştir:

“Bugün Asya ve Afrika’nın pek çok ülkesi kolonyal sömürü düzeni yüzünden ekonomik olarak geri kalmış durumdadır; ancak Batılı güçlerin kaderlerimizi kontrol ettikleri günler çoktan geride kaldı. Tam bağımsızlık, çok sayıdaki Asya ve Afrika ülkesinin uğruna uzun süre mücadele etmesi gereken bir amaçtır" (Zhou, 1955).

Başbakan Zhou liderliğinde Çin'in Bandung Konferansı'nda vurgulamaya çalıştığı nokta Batı sömürgeciliğine karşı topyekûn ve kararlı bir mücadele verilmesi gerektiğidir. Daha önce Mao'nun teorisinde belirtildiği gibi Ortadoğu da sömürgeci düzenden kurtulması ve bir gün tekrar böyle bir düzenin parçası olmaması için çaba sarf edilmesi gereken bir bölge olarak görülüyor algilaniyordu. Mao'nun dünya teorisine ilave olarak Başbakan Zhou'nun 1953 yılında açıkladığı ve Bandung Konferansı'nda vurguladığı 5 prensip gerek dönemin Ortadoğu politikasına gerek daha uzun vadede Çin dış politikasına çerçeve sunmaktadır. Bu 5 prensip; her ulusun toprak bütünlüğüne ve egemenliğine karşılıklı saygı, saldırmazlık, iç işlerine müdahale etmeme, eşitlik ve karşılıklı kazanım, barışçıl bir arada yaşama ilkeleridir. Bu ilkelerle (Zhou, 1953) uyumlu olarak Çin, Mısır'ın Süveyş Kanalı'nı millileştirme kararına, İran'ın petrol endüstrisinin egemenliği mücadelesine, Ortadoğu halklarının ulusal bağımsızlık ve özgürlük davalarına ve Filistin halkının hak mücadelesine desteğini açıç̧a ifade etmiştir (Wang, 2010: 19).

Ortadoğu'da var olan karşıt veya çatışmalı aktörler arasında ise Çin bir tarafı destekleyerek diğerini görmezden gelmek yerine çoğunlukla iki tarafla da ilişki kurmayı tercih edegelmiştir. Bunun en belirgin örnekleri Suudi Arabistan-İran çekişmesi ve Filistin-İsrail çatışmasıdır. Bunun temelinde yine bölge içi çatışmaların Batılı güçlerin bir nüfuz alanı mücadelesi olarak görülmesi yatmakta ve bölgenin istikrara kavuşması için anti-emperyalist duruşun desteklenmesi gerekliliği vurgulanmaktadır. Bu yaklaşımı birkaç örnek ile somutlaştırmak mümkündür. Misır lideri Nasır'ın 1956 yılında Süveyş Kanalı'nı millileştirme kararının ardından yaşanan krizde Mısır'a en büyük desteği Sovyetler Birliği'nin ardından Çin vermiştir. 1958 yılında ABD’nin Lübnan'a, İngiltere'nin de Ürdün'e müdahaleleri Çin tarafından kınanmış akabinde de Irak ile diplomatik ilişkiler kurulmuştur.

1950'li yıllarda izlenen diplomatik tanınmayı artırma ve anti-emperyalist mücadeleyi destekleme -büyük oranda bilhassa ekonomik imkânların ve iç 
politikanın elverdiği ölçüde söylem düzeyinde kalmış olsa da - sütunları üzerine inşa edilen Çin dış politikası 1960'lı ve 1970'li yıllarda bazı noktalarda süreklilik arz etmekle birlikte kimi hususlarda değişiklikler de göstermiştir.

1960’lı ve 1970'li yıllar Çin için gerek iç politika, gerek diş politika alanlarında hareketli ve zorlu yıllar olmuştur. 1960'ların başındaki en önemli gelişmelerden biri Çin ve Sovyetler Birliği arasında yaşanan ideolojik ayrışmadır. Bu ideolojik farklılaşma, Çin'in Ortadoğu ülkelerinden Sovyetler Birliği ile yakın ilişkisi olan ve olmayan ülkelere karşı yaklaşımını da doğrudan etkilemiştir. Örneğin; Mısır ve Suriye Sovyetler Birliği ile daha yakın ilişkiler kurduğu için Çin bu ülkelerle ilişkisinde daha mesafeli bir tavır içine girmiş, öte yandan Türkiye ve İran gibi daha Batı bloğunda olan ülkelerle ilişkisini geliştirmeye çalışmıştır (Pan, 1997: 37).

1966-1976 yılları arasındaki Çin'de, Büyük Proleter Kültür Devrimi iç politikada önemli etkiler meydana getirmiştir. Bunun dış politika alanına da yansımaları olmuştur. Çin'in Ortadoğu'daki tüm büyükelçileri - Mısır hariç - merkeze çağrılmış; Kültür Devrimi'nin başlangıcından 1970 yılına dek Çin ve Ortadoğu ülkeleri arasında herhangi bir üst düzey resmi ziyaret gerçekleştirilmemiştir (Wang, 2010: 20). Diğer yandan, 1971 yılında Çin’in BM Güvenlik Konseyi daimi üyeliğini elde etmesi Çin'in Ortadoğu ülkeleriyle 1950'li y1llardan bu yana kurduğu ve geliştirdiği siyasi ilişkilerin bir meyvesi olarak görülebilir. BM 26. Genel Kurulu'nda ÇHC'nin Çin halkının tek meşru temsilcisi olarak görülmesi ve haklarının tesis edilmesine dair yapılan oylamada 15 Ortadoğu devleti lehte oy kullanmıştır. Aynı yıl, Kuveyt, Lübnan ve İran ÇHC ile diplomatik ilişkiler kurmuş; bu üç ülkeyi Ürdün, Umman ve Libya takip etmiştir. Kültür Devrimi yıllarında, Çin’in Sovyetler Birliği ile fikir ayrılığı daha da kendini hissettirmiş ve Ortadoğu'ya bakışını da temel olarak Sovyetler karşıtı bir çerçevede şekillendirmiştir. Bunu yaparken yine de diplomatik kanallar ilk olarak tercih edilmiş, Ağustos-Kasım 1971 döneminde İran, Türkiye ve Lübnan ile diplomatik ilişkiler kurulmuştur.

Diplomatik ve siyasi ilişkilerin sağlanmasına ve derinleştirilmesine verilen önem ekonomik alanda da kendini göstermiştir. Çin, özellikle doğrudan yardımlar vasıtasıyla bölgedeki ekonomik varlığını artırmaya özen göstermiştir. 1963 yılının sonuna kadar Ortadoğu ülkeleri Çin yardımlarından \% 8 pay almaktaydı (\% 61 Asya bölgesine, \% 31 ise Afrika bölgesine gidiyordu); 1964 yılına gelindiğinde ise, Ortadoğu'nun Çin yardımlarından aldığı pay \% 32'ye yükselmiştir (aynı yıl Asya'nın aldığı pay \% 34'e düşerken Afrika'nın payı da \% 34'e yükselmiştir) (Shichor, 1979: 114). 


\section{8-2013 Döneminde Çin Dış Politikası ve Ortadoğu}

1978 yılında Mao'nun ölümünün ardından Çin Devlet Başkanı olan Deng Xiaoping 1992 yllında kadar bu görevini sürdürmüştür. Mao'nun ve Zhou'nun ölümünün ardından kimin liderlik edeceği sorunu da Deng'in iktidara gelişiyle beraber netlik kazanmıştı. Ancak, özellikle Kültür Devrimi'nden sonra insanların yönetime olan inançlarını ve güvenlerini yeniden tesis edecek bir lider veya bir yaklaşım aranmaktaydı. Deng daha reformcu yaklaşımı ile birlikte Çin ekonomisini aşama aşama dünya ekonomisine açma ve entegre etme kararını hayata koymaya başladı. Ekonomik reformların yanı sıra Deng dönemini kendinden önceki dönemlerden ayıran bir başka özelliği daha bulunmaktadır. Bu da Deng döneminde, Mao dönemine kıyasla daha az ideolojik bir yaklaşımın sergilenmesidir. Azalan ideolojik vurgunun yerini daha pragmatik ve yoğun diplomatik ilişkiler doldurmuştur. Çin, o noktada artık herhangi bir ülkenin Washington ve Moskova olan ilişkilerine dayanarak dost veya düşman ülke tanımlaması yapmamaya başlamış ve Çin'in faydasına olan şey karar alma mekanizmasının tam odağına yerleştirilmiştir (Pan, 1997: 38). $\mathrm{Bu}$ yüzden mümkün olduğunca fazla bölge ülkesi ile ilişki kurmanın yolları aranmış; 1977'den 1990 yılına kadar olan dönemde Ürdün, Umman, Libya, Birleşik Arap Emirlikleri, Katar, Bahreyn, Suudi Arabistan ve Filistin ile diplomatik ilişkiler kurulmuştur.

Diplomatik ilişkiler rayına otururken bir yandan bölgede patlak veren İran-Irak Savaşı (1980-1988) Çin'in bölgeye silah ticaretinin kapısını aralamış oldu. Zira Çin hem İran’a hem Irak’a silah satmış ve bu da Çin-İran ilişkilerinin tarihine kayda değer bir etki etmiştir (Neill, 2014: 208). Savaş döneminde yoğunlaşan silah ihracı takip eden yıllarda da düzenli olarak devam etmiş; bugün de Çin ve İran arasındaki silah ticareti önemini koruyarak devam etmektedir. İran ve Çin arasındaki ilişkilerin günümüzde daha da yakınlaşmasının bir diğer nedeni de ABD yönetiminin tavrıdır. Zira Trump iktidara geldikten sonra İran ile nükleer görüşmeler askıya alınmış ve daha sert bir politika takip edilmeye başlanmıştır (Öztürk, 2018: 166). Bu da bölgede daha baskıcı ve sert bir ABD'nin tepkiyle karşılanmasına ve bir anlamda İran'ın Çin'e daha fazla sarılmasına vesile olmuştur.

Reformlar sayesinde büyüyen Çin ekonomisinin artan enerji ihtiyacı bugün olduğu gibi 1980'li ve 1990'lı yıllarda da Ortadoğu ülkeleri ile olan ekonomik ilişkisini etkileyen en belirgin ihtiyaç olmuştur. 1997 yılında devlet himayesinde olan Çin Ulusal Petrol Şirketi (China National Petroleum Corporation) Saddam Hüseyin hükümeti ile bir petrol anlaşması imzalamış ve Al-Ahdab petrol bölgesinin geliştirilmesi konusunda anlaşmıştır. Ancak 
bu anlaşma bir türlü hayata geçememiş, 2003'teki ABD’nin Irak'1 işgalinin ardından ise Saddam döneminde imzalanan anlaşmalar hükümsüz hale gelmiştir. Çin, ABD ve İngiltere'nin Irak'ın işgaline karşı çıkmış fakat Irak'ın yeniden inşası aşamasında dışarıda kalmamış ve savaş sonrası Irak’a önemli destekler vermiştir. Başlangıç olarak Irak’a 25 milyon dolar yardım sözü vermiş ve Irak'ın Çin'e olan borcunun ciddi bir kısmını silmiştir (Zhu, 2009: 42). Haziran 2004'te Irak geçici hükümetinin göreve gelmesini takip eden iki hafta içerisinde Çin Büyükelçiliği tekrar açılmıştır. Çin'in Irak’a sağladığı diğer destekler arasında; Irak seçimlerinde maddi destek sağlama, Iraklı öğrencilere Çin'de burslu eğitim imkânı sunma ve Irak diplomatlarını Çin Dış İlişkiler Üniversitesi'nde eğitme de bulunmaktadır. Çin hükümetinin bu cömert yardımları tamamen naif bir niyetten ziyade yakın gelecekte gerçekleşecek büyük petrol ve altyapı yatırım projelerinin ihalelerine dâhil olmayı ve bu projelerin üstlenilmesini hedeflemekteydi (Mao, 2005).

Çin'in büyüyen ekonomisini istikrarlı düzeyde tutabilmesi için sadece kendi ürettiği petrol yeterli gelmemektedir. Ulusal Kalkınma ve Reform Komisyonu'nun açıkladığı verilere göre 2009 yılında Çin'in ham petrol üretimi 189,4 milyon ton olup bu miktar iç talebin sadece yarısını karşılayabilecek seviyededir (Qian, 2010: 66). Bu üretim miktarı ile Çin, 2009 yılında Rusya, Suudi Arabistan ve ABD’nin ardından 4. büyük petrol üreticisi olmuştur. Fakat bu yeterli olmadığı için diğer ülkelerden petrol ithal edilmesi zorunluluğu Çin'i petrol diplomasisine önem vermeye mecbur bırakmaktadır. İran, Suudi Arabistan, Kuveyt ve Irak Çin'in enerji ihtiyacının karşılanmasında Ortadoğu'daki en önemli ülkelerdir. Bu önemi somutlaştırmak adına Çin, 2004 yılının Temmuz ayında Arap Körfez İşbirliği Konseyi ile serbest ticaret bölgesinin kurulması için müzakerelere başladı. 2005 yılının Aralık ayı sonunda Kuveyt Enerji Bakanı Şeyh Ahmad Fahad Al-Ahmad Al-Sabah ve beraberindeki OPEC heyeti Çin'i ziyaret ederek dünya enerji pazarı ve Çin'in muhtemel enerji ihtiyacı hakkında temaslarda bulunmuştur.

Bir diğer önemli ziyaret de Suudi Arabistan tarafından gerçekleştirilmiştir. Suudi Arabistan Kralı Abdullah 2006 yılında Asya ziyaretleri kapsamında Çin'i ziyaret etmiştir. Bu ziyaret sadece Asya'daki ilk durağının Çin olması bakımından değil aynı zamanda Kral Abdullah'ın iktidara geldiği andan itibaren Ortadoğu dışına gerçekleştirdiği ilk yurtdışı ziyareti olması bakımından da son derece önemlidir (Shichor, 2006: 40). 23 Ocak 2006 tarihinde Çin Devlet Başkanı $\mathrm{Hu}$ Jintao ile görüşen Kral Abdullah iki ülke arasında biri daha yakın enerji işbirliğini öngören anlaşma olmak üzere toplam beş anlaşmaya imza atmışlardır. Başta Suudi Arabistan ve Birleşik Arap Emirlikleri olmak üzere Çin ve Ortadoğu ülkeleri arasındaki temel ticaret kalemini enerji ithalatı 
oluşturmaktadır. Fakat özellikle Körfez ülkeleri tek ürüne dayalı birer ekonomik oldukları için Çin'den ithal ettikleri ürünler gerek günlük hayat gerek endüstriyel ihtiyaçlar için büyük önem taşımaktadır (Qian ve Fulton, 2017: 14).

Siyasi, ekonomik ve güvenlik ilişkilerinin ivme kazanmasının ardından Çin, Ortadoğu coğrafyasında yumuşak güç unsurları ile de var olma çabası içindedir. Son yıllarda özellikle artan yatırımlarının etkisi nedeniyle Çinceye kayda değer bir ilgi mevcuttur. Çin dili ve kültürünün öğretilmesi ve yaygınlaştırılması amacıyla hizmet veren Konfüçyus Enstitüleri'nin ilki 2004 yılında Seul'de açılmıştır. Son yıllarda Ortadoğu'nun farklı ülkelerinde de açılmaya başlamıştır. Çin'in Ortadoğu'daki ilk Konfüçyus Enstitüsü 2006 yılında Beyrut'ta St. Joseph Üniversitesi'nde açılmış; ardından Ekim 2007'de Tahran Üniversitesi'nde ve Kasım 2007'de Tel Aviv Üniversitesi'nde hizmete girmiştir (Zhu, 2009: 45-46). Türkiye'deki ilk Konfüçyus Enstitüsü 28 Kasım 2008 tarihinde Orta Doğu Teknik Üniversitesi bünyesinde açılmıştır. Ardından Boğaziçi Üniversitesi'nde 2010 yllında, Okan Üniversitesi'nde ise 14 Mayıs 2013 tarihinde birer Konfüçyus Enstitüleri açılmıştır. Son olarak ise Yeditepe Üniversitesi Konfüçyus Enstitüsü 27 Eylül 2017 tarihinde açılmıştır.

\section{3'ten Günümüze Çin Dış Politikası ve Ortadoğu}

Mevcut Devlet Başkanı Xi Jinping’in 2013 yılının Mart ayında iktidara gelişi ile birlikte Çin dış politikası için yeni bir dönemin başladığı bugün geriye bakıldığında daha net olarak anlaşılmaktadır. Bunun en temel göstergelerinden biri de yüzyllın projesi olarak nitelendirilen Kuşak ve Yol İnisiyatifi'nin Xi Jinping tarafından ilan edilmesidir. Kara ve deniz ipek yolu şeklinde iki temel rotayı canlandırmayı hedefleyen bu proje onlarca ülkeyi ve milyonlarca insanı bünyesine dâhil ederek uzun vadede önemli etkileri olacağını açıklandığı andan itibaren hissettirmiştir. Zira projeye destek veren ve bir parçası olmayı memnuniyetle dile getiren ülkeler olduğu kadar, daha şüpheci yaklaşan ülkeler de mevcuttur. ABD'nin başı çektiği bu şüpheci ve eleştirel grupta Hindistan ve Japonya da bulunmakla birlikte Ortadoğu ülkelerinin tamamına yakını pozitif bir yaklaşım sergilemektedirler.

Kuşak ve Yol Projesi'nin Ortadoğu'yu ilgilendiren iki önemli parçası Çin-Pakistan Ekonomik Koridoru (China-Pakistan Economic Corridor, CPEC) ve Çin-Orta Asya-Batı Asya Ekonomik Koridoru'dur (China-Central Asia-West Asia Economic Corridor, CCWAEC). Büyük oranda altyapı ve ulaşım projelerinden oluşan bu büyük planların hayata geçirilebilmesi için sadece finansal kaynağın sağlanması yeterli değildir; geçtiği coğrafyalarda siyasi istikrarın bulunması ve sürmesi, ayrıca iktidardaki hükümetlerle Çin'in yakın ilişki için- 
de olması da gerekmektedir. Bölgenin jeo-stratejik önemi de Çin'in Avrupa pazarlarına ulaşabilmesini mümkün kıldığından son derece açıktır. Bu projeler aynı zamanda Ortadoğu'nun kendi içinde de yatırım anlamında bir hareketlilik ortaya çıkarmaktadır. Örneğin, Suudi Arabistan, Çin-Pakistan Ekonomik Koridoru'nun bir parçası olmak üzere Pakistan'a 16 milyar dolar değerinde kredi ve yatırım desteği önermiş; bunun 10 milyar doları ise Pakistan'ın Gwadar şehrine yapılacak olan petrol rafinerisi ve petro-kimya kompleksi yatırımına yöneliktir. Esasen Çin'in Kuşak ve Yol Projesi Çin’i ekonomik olarak daha güçlü ve yaygın bir ağa kavuşturacak olmasının yanı sıra Ortadoğu ülkeleri için de önemli fırsatlar sunmaktadır. Daha önce de belirtildiği gibi Ortadoğu ve özellikle Körfez ülkelerinin çok yüksek oranda petrol endüstrisine dayalı ekonomileri sürdürülebilirlik noktasında riskler taşımaktadır. Petrol ve doğalgaz rezervlerinin bir gün tükenecek olması bölge ülkelerini ekonomilerini yeni alanlara kaydırma ve adapte etme mecburiyetine yönlendirmiştir. Bu durumun en fazla farkında olan ve çözüm arayan ülkelerin başında Suudi Arabistan ve Birleşik Arap Emirlikleri gelmektedir. Suudi Arabistan, Pakistan'daki yeni yatırımları ile Aramco'nun enerji yatırımlarını çeşitlendirmek ve farklı bölgelere yaymak istemektedir. Birleşik Arap Emirlikleri ise Çin'in Kuşak ve Yol Projesi'nin deniz ipek yolu rotası sayesinde canlanacağını düşündüğü deniz ticaretinin hacmini karşılayabilmek adına Çin'in en büyük nakliye şirketi olan COSCO ile anlaşmalar imzalamış ve bu doğrultuda Abu Dabi limanlarına yeni terminaller yapmayı hedeflemektedir (Saidi, 2018).

Çin, 2016 yılında açıkladığı Arap Politika Metni’nde Ortadoğu ülkelerine Kuşak ve Yol Projesi bağlamında atfettiği önemi bir kez daha vurgulamaktadır. Çin, bu metinde Arap ülkelerini barışcıl kalkınma yolunu takip eden, gelişmekte olan ülkeler arasında birliği ve işbirliğini güçlendiren ve özünde kazan-kazan işbirliğinin yattığı yeni bir uluslararası ilişkiler düzeninin kurulmasına yardımcı olan önemli partnerler olarak tanımlamaktadır (China's Arab Policy Paper, 2016). Ekonomik işbirliği vurgusunun yanında siyasi meselelere de değinilen metinde özellikle Filistin konusu dikkat çekicidir. Çin, Ortadoğu barış sürecini desteklediğini vurgularken; Filistin konusunda 1967 öncesi sınırların esas alındığı ve Doğu Kudüs'ün başkent olarak kabul edileceği bir çözüme desteğini de açıkça ifade etmektedir. Ayrıca Arap Ligi'nin bu konudaki adımlarının da destekçisi olduğunu belirtmektedir. Çin, Ortadoğu ülkeleriyle olan ilişkisini genişletmek ve derinleştirmek için 5 ana başlık belirlemiştir. Bunlar siyasi işbirliği, yatırım ve ticaret işbirliği, sosyal kalkınma, kültürel ve ikili insani ilişkilerin alışverişi ve bölgesel güvenliktir. Ayrıca her birine alt başlıklar tanımlanan bu alanlarda Çin, nükleer teknolojilerden 
uzayda işbirliğine, tarımdan finansa kadar pek çok konuda işbirliğini ve teknik desteğini garanti etmiştir.

Bu bağlamda Xi Jinping 19-23 Ocak 2016'da Ortadoğu turuna çıkmış ve Suudi Arabistan, İran ve Misır'ı ziyaret etmiş ve toplamda 52 işbirliği metnine imza atmıştır. (Yi, 2016). Bunların 14'ü Suudi Arabistan ile 21'i Mısır ile 17'si ise İran ile imzalanmıştır. Suudi Arabistan ziyaretindeki önemli bir nokta da Çin ve Suudi Arabistan ortak projesi olan Arabistan'ın Yanbu şehrindeki YASREF (Yanbu Aramco Sinopec Refining Company, Yanbu Aramco Sinopec Rafine Şirketi) petrokimya rafinerisinin yapımının Xi'nin ve Suudi Kralı Salman bin Abdulaziz Al Saud'un katıldığı törenle başlatılmasıdır. Yasref, Çin'in Suudi Arabistan'daki en büyük yatırım projesi olması bakımından ayrı bir öneme sahiptir.

Xi Jinping'in Ortadoğu turundaki bir diğer durak da Mısır olmuştur. Diplomatik ilişkilerin kurulmasının 60. Yllı kutlamalarına katılan Mısır Cumhurbaşkanı Abdel Fattah al-Sisi ve Xi görüşmeleri neticesinde, 2016 yılını Çin'de Mısır Kültürü yılı, Mısır'da da Çin Kültürü yılı ilan etmişlerdir. İran'ı da ziyaret eden Xi, Suudia Arabistan ile İran arasında seçim yapmaktan ziyade, ikisi ile de işbirliğini en üst düzeyde tutmaya gayret ettiğini bir kez daha göstermiş bulunmaktaydı. Zira İran, Suudi Arabistan'ın ardından Çin'e en fazla petrol ihraç eden ikinci ülkedir.

Xi döneminde Çin dış politikasının Ortadoğu ayağındaki en önemli siyasi gündem maddelerinden bir diğerini de kuşkusuz Suriye savaşı teşkil etmektedir. 2011 yılının başlarında halkın reform talepleri ile başlayan sokak gösterileri zaman içerisinde tüm ülkeye yayılan bir iç savaş haline evrilmiştir (Tinas, 2019: 106). Suriye savaşı Çin için salt siyasi önem arz eden bir konu olmamakta, Kuşak ve Yol Projesi'nin geçeceği bölgenin güvenliğini de doğrudan ilgilendirmektedir. Suriye'nin Çin'in Ortadoğu'ya yaklaşımında Suudi Arabistan ve İran kadar stratejik bir öneme sahip olmadığı görülebilen bir gerçekliktir; lakin bu durum Çin'in Suriye konusuna duyarsız kaldığı anlamına da gelmemektedir. 2011'de başlayan iç çatışma bugün birçok ülkenin de dâhil olduğu uluslararası bir savaş haline evirilmiştir. Çin, Suriye konusunda daha temkinli ve BM'yi temel alan bir yaklaşım sergilemekle birlikte işbirliğine de 1949'dan beri önem vermektedir. Çin ve Suriye arasında bilhassa askeri alanda işbirliği bulunmaktadır. 2004 yılının mayıs ayında Çin, Suriye'nin orta menzilli Scud füze programını geliştirebilmesi için teknik uzman ekip göndermiştir (Daher, 2009: 22).

Çin dış politikasının temel prensiplerinden olan egemenliğe saygı ve iç işlerine müdahale etmeme Suriye vakasında da izlenmektedir. 2014 Ocak 
ayında İsviçre'de gerçekleştirilen Cenevre II. Barış Konferansı'nda konuşan Çin Dışişleri Bakanı Wang Yi Çin'in Suriye'de siyasi bir çözüm için yaklaşımı$\mathrm{n} ı$ beş prensip temelinde ortaya koymuştur. Bunlar; Suriye konusunun siyasi yollar aracılığıyla çözülmesi, Suriye'nin geleceğine Suriye halkının karar vermesi, kapsayıcı bir siyasi geçiş sürecinin desteklenmesi, ulusal uzlaşma ve birliğin sağlanması, Suriye ve komşularına insanı yardım sağlanması gerekliliğidir (Wang Yi Proposes Five Principles to Facilitate a Political Settlement of Syrian Issue, 2014). Suriye konusunda toplanan Cenevre I. Barış Konferansı'na (2012), Cenevre II. Barış Konferansı'na (2014) ve Viyana Barış Görüşmeleri'ne (2015) de katılan Çin, 2017 yılında Rusya, İran ve Türkiye tarafından oluşturulan Astana Barış Süreci'ni de memnuniyetle karşılamış ve bunun Cenevre sürecine kıymetli bir katkı olacağını ifade etmiştir (Foreign Ministry Spokesperson Hua Chunying's Regular Press Conference on January 20, 2017, 2017). Xi Jinping'in Ortadoğu ziyaretinin ardında Çin, 2007-2010 yılları arasında İran Büyükelçisi olarak görev yapan Xie Xiaoyan'ı Suriye Özel Temsilcisi olarak görevlendirmiştir. Görevi kapsamında sık sık bölge ülkelerini ziyaret eden ve Suriye'nin durumuna dair görüş alışverişinde bulunan Xie, 20 Ağustos 2019'da Cenevre'de yaptığı açıklamada Rusya'nın Suriye'deki teröristlere yönelik düzenlediği hava saldırıları sayesinde terörle mücadeleye büyük destek sağladığını ve Çin'in de Suriye'de barışın sağlanmasına pozitif bir destekçi olarak yoluna devam edeceğini ifade etmiştir (Qi, 2019).

Tüm bu siyasi girişimlerin ve krizin doğrudan bir parçası olmama çabasının yanında Çin diğer kanalları daha aktif olarak kullanma yolunu tercih etmiştir. Buna en belirgin örnek insani yardımdır. Gerek ikili gerek çok taraflı platformlar aracılığıyla Çin, Suriye’ye önemli insani yardım sağlamaktadır. 18 Ocak 2017'de BM’nin 71. Genel Meclisi'nde yaptığı konuşmada Xi, Suriyeli göçmenlere ve ülke içinde yerlerini değiştirmek zorunda kalan insanlara yardım için 200 milyon Yuan (yaklaşık 29 milyon dolar) değerinde bir insani yardım paketi sağlayacaklarını açıklamıştır (Xi, 2017). Aynı yıl Dünya Gıda Programı aracılığıyla Ürdün'e sığınan Suriyeli göçmenler için 1.5 milyon dolar değerinde gıda desteği sağlanmıştır (WFP, China conclude food aid programme for Syrian refugees, 2018). Çin'in Suriye krizinin başlangıcından bugüne dek gerek gıda yardımları gerek sağlık hizmetlerinin sağlanabilmesi için verdiği tüm insani destekler uluslararası platformda profiline oldukça olumlu katkılar sağlamaktadır. 


\section{Sonuç}

Çin, 1950'li yıllarda diplomatik olarak tanınma ve sömürge düzeninin ortadan kaldırılarak bağımsızlık hareketlerini destekleme temelinde kurguladığı Ortadoğu politikasında zaman zaman değişimler yaşamış ve fakat beraberinde süreklilikler de göstermiştir. 1971 yılında BM'ye ve Güvenlik Konseyi'ne dönene kadar esas olarak diplomatik tanınma ve ilişkilerin kurulmasına çaba sarf etmiştir. Bu çabaların bir kısmı daha kısa sürede sonuç vermiş ancak bazıları ancak 1980'lerin sonunda hatta 1990'ların başlarında başarıya ulaşmıştır. 1978'deki reform sürecinin başlamasının ardından yüksek büyüme oranlarının yakalandığı Çin ekonomisi için temel öncelikler enerji akışının sağlanması ve güvenliği olmuştur. Bu noktada özellikle en büyük enerji sağlayıcıları olan Suudi Arabistan, Birleşik Arap Emirlikleri, İran ve Irak ile ilişkilerini geliştirmeye azami gayret göstermektedir. 2013 yılı itibariyle Çin'in uluslararası arenada gözle görülür bir etkinliğe kavuşma çabası Kuşak ve Yol Projesi ile deklare edilmiştir. Bu projenin temelinde her ne kadar ekonomik ve ticari hedeflerin yattığı vurgulansa da ticari büyüklüğü ve geçtiği coğrafya göz önüne alındığında böylesi devasa bir projenin siyasi etkiler doğuracağı ve siyasi hedeflerinin de olabileceği açıktır. Bu doğrultuda Çin pazarını Avrupa'ya daha hızlı şekilde bağlama fikrinde Ortadoğu ülkeleri de kritik bir yerde durmaktadır. Gerek büyük enerji sağlayıcıları olmaları gerek Çin için potansiyeli yüksek tüketim toplumları olmaları gerekse yeni İpek yolu üzerindeki stratejik konumları sebebiyle Çin Ortadoğu ülkelerine ciddi ilgi göstermektedir. Bu aşamada görülen en büyük riskin bölge içindeki farklı etnik ve dini temelli ayrışmalar olduğu söylenebilir. Daha önce de değinildiği gibi Suudi Arabistan-İran ve Filistin-İsrail eksenli çatışmalarda Çin tarafsızlığını korumaya dikkat etmekte, tüm aktörler ile ilişkilerini derinleştirmeye çalışmaktadır. Bunu da kurulduğu 1949'dan bu yana hem tüm taraflarla ticari anlaşmalar yaparak ve her iki tarafa yatırımlarını sürdürerek hem temel prensipleri olan egemenlik ve toprak bütünlüğüne saygı ve iç işlerine müdahale etmemeye büyük hassasiyet göstererek sürdürmektedir.

Tüm bu olumlu gidişatın içindeki mevcut en büyük risk ise devam eden Suriye savaşıdır. 2011'de başlayan krize mümkün olduğunca doğrudan katılmamaya özen gösteren Çin, sahadaki varlığını daha ziyade insani yardım programları çerçevesinde oluşturmaktadır. Krizin çözümü için de her defasinda siyasi diyalog vurgusu yapan Çin çözüm için de BM'nin platform olarak görülmesi gerektiğinin altını çizmektedir. Ancak Suriye krizi başta bölge halkı için olduğu kadar Çin'in bölgedeki yatırımları için de bir risk oluştururken, madalyonun diğer yüzüne bakıldığında fırsatların da bulunduğu görül- 
mektedir. Zira savaşın sona erdiği andan itibaren başlayacak olan Suriye'nin yeniden inşa edilmesi süreci Çin tarafından ekonomik bir fırsat olarak alg1lanmaktadır. Bu amaçla her ne kadar sahada savaşan ülkelerden biri olmasa da Suriye rejimi ile ilişkiler hiç bir zaman kesintiye uğratılmamış ve savaş sonrası dönem için dostane bir ortak olma durumu korunmaya çalışılmıştır. Bu bağlamda, Çin dış politikasında Ortadoğu coğrafyasının ekonomik, politik ve stratejik ilişkilerin sürdürülmesinin elzem olduğu ve karşılaşılan sorunların tarafı olmaktansa mümkün olduğunca sorunun parçası olan aktörlerin yanında yer almanın önemsendiği bir bölge olduğunu söylemek mümkündür.

\section{Kaynakça}

An, Jiang (2013), Mao Zedong's “Three Worlds” Theory: Political Considerations and Value for the Times, Social Sciences in China, ss. 35-57.

Calabrese, John (2019), “China and Syria: In War and Reconstruction”, Middle East Instiute, 9 June 2019, https://www.mei.edu/publications/china-and-syria-war-and-reconstruction (E.T: 01 Ocak 2020).

China's Arab Policy Paper (2016), Beijing, China. http://english.www.gov.cn/archive/publications/2016/01/13/content_281475271412746.htm (E.T: 15 Aralık 2019).

Daher, Massoud (2009), “China and the Middle East: Establishing a New”, Journal of Middle Eastern and Islamic Studies (in Asia), 3(1), ss. 18-36. https://doi.org/10.1080/1937067 9.2009.12023120 (E.T: 10 Aralık 2019).

Foreign Minister Wang Yi's Comments on President Xi Jinping's Visits to Saudi Arabia, Egypt, Iran and Headquarters of League of Arab States (2016, Ocak 24), Embassy of the People's Republic of China in the Kingdom of Saudi Arabia: http://sa.china-embassy.org/ eng/zt/2/t1335497.htm (E.T: 12 Aralık 2019).

Foreign Ministry Spokesperson Hua Chunying's Regular Press Conference on January 20, 2017 (2017, Ocak 20), Ministry of Foreign Affairs of the People's Republic of China: https:// www.fmprc.gov.cn/mfa_eng/xwfw_665399/s2510_665401/t1432311.shtml (E.T: 10 Aralık 2019).

Full Text of Xi Jinping keynote speech at the United Nations Office in Geneva (2017, Ocak 18), CGTN America: https://america.cgtn.com/2017/01/18/full-text-of-xi-jinping-keynote-speech-at-the-united-nations-office-in-geneva (E.T: 15 Aralık 2019).

Mao, Yufeng (2005), “Beijing's Two-Pronged Iraq Policy”, China Brief, The Jamestown Foundation: https://jamestown.org/program/beijings-two-pronged-iraq-policy/ (E.T: 16 Aralık 2019).

Neill, Alexander (2014), “China and the Middle East”, Adelphi Papers, ss. 205-224.

Olimat, Muhamad S. (2014), China and the Middle East Since the World War II, Maryland: Lexington Books.

Oosterveld, Willem (2017, Ağustos 25), "China in the Middle East: Testing the Waters, Linking the Lands”, The Diplomat: https://thediplomat.com/2017/08/china-in-the-middle-east-testing-the-waters-linking-the-lands/ (E.T: 13 Aralık 2019). 
Öztürk, Selim (2018), “iran’da Silahlı Muhalefetten Demokrasi Söylemlerine:Halkın Mücahitleri Örgütü”, Güvenlik Çalışmaları Dergisi, s. 2, Ankara, ss. 165-175.

Pan, Guang (1997), “China's Success in the Middle East”, Middle East Quarterly, ss. 35-40. https://dev.meforum.org/373/chinas-success-in-the-middle-east

Tınas, Murat (2019), "Grand Rivalry on Grand Tragedy: The US and Russia in the Syrian Civil War”, Fulya Köksoy (ed.), Global and Regional Powers: Relations, Problems and Issues in the 21st Century, Berlin: Peter Lang, ss. 103-123.

Qi, Ren (2019, Ağustos 20), "Chinese special envoy: Political solution only way ahead for Syria", China Daily: https://global.chinadaily.com.cn/a/201912/23/WS5e0018a4a310cf3e3557fe63.html (E.T: 13 Aralık 2019).

Qian, Xuewen (2010), “China’s Energy Cooperation with Middle East Oil-producing Countries", Journal of Middle Eastern and Islamic Studies (in Asia), ss. 65-80.

Qian, Xuming ve Fulton, Jonathan (2017), "China-Gulf Economic Relationship under the "Belt and Road” Initiative”, Asian Journal of Middle Eastern and Islamic Studies, ss. 12-21.

Saidi, Nasser (2018, Nisan 12), "China's Belt \& Road: new avenues for Middle East growth and economic diversification", The National: https://www.thenational.ae/business/economy/ china-s-belt-road-new-avenues-for-middleeast-growth-and-economic-diversification-1.720919 (E.T: 14 Aralık 2019).

Shichor, Yitzhak (1979), The Middle East in China's Foreign Policy: 1949-1977, London: Cambridge University Press.

Shichor, Yitzhak (2006), “Competence and Incompetence: The Political Economy of China's Relations with The Middle East", Asian Perspective, ss. 39-67.

Takahashi, Nobuo (1990), "The Chinese Communists and the Theory of Intermediate Zone during the 1950s", Japan Association of International Relations, ss. 63-78. https://www. jstage.jst.go.jp/article/kokusaiseiji1957/1990/95/1990_95_63/_article (E.T: 5 Aralık 2019).

Wang Yi Proposes Five Principles to Facilitate a Political Settlement of Syrian Issue (2014, Ocak 20), The Ministry of Foreign Affairs of the People's Republic of China: https:// www.fmprc.gov.cn/mfa_eng/wjb_663304/zzjg_663340/xybfs_663590/xwlb_663592/ t1124573.shtml (E.T: 12 Aralık 2019).

Wang, Jinglie (2010), "Review and Thoughts over the Relationship between China and the Middle East”, Journal of Middle Eastern and Islamic Studies (in Asia), ss. 16-39.

WFP, China conclude food aid programme for Syrian refugees (2018, Mart 14), The Jordan Times : http://www.jordantimes.com/news/local/wfp-china-conclude-food-aid-programme-syrian-refugees (E.T: 12 Aralık 2019).

Zhou, Enlai (1955, April 19), Main Speech by Premier Zhou Enlai, Head of the Delegation of the People's Republic of China, Distributed at the Plenary Session of the Asian-African Conference. Digital Archive Wilson Center: https://digitalarchive.wilsoncenter.org/document/121623.pdf?v=e1cd06384e2e67bdff1 1f809ead78849 (E.T: 11 Aralık 2019).

Zhou, Enlai (1953, Aralık 31), The Five Principles. Zhou Enlai Peace Institute: http://www. zhouenlaipeaceinstitute.org/five-principles-of-peace-2/history/ (E.T: 11 Aralık 2019).

Zhu, Zhiqun (2009), “China's New Diplomacy in the Middle East and Its Implication for the United States", Journal of Middle Eastern and Islamic Studies (in Asia), ss. 41-52. 